\title{
Differential secretion of interleukin-12 (IL-12) subunits and heterodimeric IL-12p70 protein by CD-1 mice and murine macrophages in response to intracellular infection by Brucella abortus
}

\author{
LUIS FERNÁNDEZ-LAGO, ELISA RODRÍGUEZ-TARAZONA and NIEVES VIZCAÍNO
}

\begin{abstract}
Departamento de Microbiología y Genética, Edificio Departamental, Universidad de Salamanca, Avda Campo
\end{abstract} Charro s/n, 37007 Salamanca, Spain

\begin{abstract}
The secretion of interleukin-12 (IL-12) following intracellular infection with virulent Brucella abortus strain 2308 was investigated in CD-1 mice and in CD-1 cultured peritoneal macrophages. Bioactive IL-12p70 and free non-immunoactive p40 subunits (IL-12p40) were determined by enzyme-linked immunosorbent assays. In CD-1 mice, $B$. abortus 2308 was a potent inducer of IL-12p40 (maximum levels were 5.9 and $3.4 \mathrm{ng} / \mathrm{ml}$ in sera and spleen homogenates, respectively). Secretion of IL-12p70 was also demonstrated in vivo, although at much lower levels $(216.6$ and $198.9 \mathrm{pg} / \mathrm{ml}$ in sera and spleen homogenates, respectively). Production of IL-12 over the first 7 days after infection was accompanied by active multiplication of $B$. abortus in the spleens of infected mice. CD-1 cultured peritoneal macrophages secreted only IL-12p40 $\left(878.4 \mathrm{pg} / 10^{7}\right.$ macrophages) in response to $B$. abortus infection and no production of IL-12p70 was observed. In contrast, CD-1 peritoneal macrophages secreted detectable amounts of IL-12p70 (16.2 pg/10 $\mathbf{7}^{7}$ macrophages) in response to purified lipopolysaccharide (S-LPS) from $B$. abortus 2308 . The macrophages also secreted significant amounts of interferon- $\gamma$ (IFN- $\gamma)\left(520.1 \mathrm{pg} / \mathbf{1 0}^{7}\right.$ macrophages) in response to intracellular $B$. abortus. These results indicate that $B$. abortus 2308 is not a potent inducer of IL-12p70 production, whereas purified S-LPS from $B$. abortus 2308 induces the secretion of this bioactive form of IL-12 in cultured peritoneal macrophages. CD-1 peritoneal macrophages were able to secrete IFN- $\gamma$, as well as high amounts of IL-12p40, in response to intracellular infection by $B$. abortus.
\end{abstract}

\section{Introduction}

Brucella abortus is a facultative intracellular bacterium and is one of the causative agents of brucellosis in animals and man [1]. Professional phagocytes are the first target for $B$. abortus invasion $[1,2]$ and the bacteria are able to survive and multiply within these cells [1-3]. Immunity to $B$. abortus depends on the effective generation of a cell-mediated response involving both $\mathrm{CD}^{+}$and $\mathrm{CD}^{+} \mathrm{T}$ cells as well as a T-celldependent activation of macrophages $[4,5]$. The cytokines secreted during this response may strongly influence this process and the outcome of the infection [6-11].

Received 20 Oct. 1998; revised version accepted 9 April 1999.

Corresponding author: Dr L. Fernández-Lago (e-mail: lrlago@gugu.usal.es).
Interleukin-12 (IL-12) is a heterodimeric cytokine composed of a heavy chain of $40 \mathrm{kDa}$ and a light chain of $35 \mathrm{kDa}$ linked by a disulphide bond [12]. In this bioactive form, with a molecular mass of $70 \mathrm{kDa}$ (IL-12p70), it is secreted mainly by monocytes and macrophages, but also by several other cell types including dendritic cells, B cells [12] and polymorphonuclear leucocytes [13]. Furthermore, the $40-\mathrm{kDa}$ subunit of this cytokine is secreted at much higher levels than the p70 bioactive form $[14,15]$. It has also been demonstrated that both the p40 monomer (p40) and the disulphide-linked p40 homodimer $(\mathrm{p} 40)_{2}$ strongly antagonise the activity of IL-12p70 $[14,16,17]$, possibly representing a novel form of self-regulating cytokine response [17]. IL-12 is a potent inducer of interferon- $\gamma$ (IFN- $\gamma$ ) production by both resting and activated $\mathrm{T}$ cells and natural killer (NK) cells; moreover, it directs the generation of T-helper type 1 responses $[16,18,19]$. This cytokine also 
enhances the cytolytic activity of a number of effector cells, including T cells, NK cells and macrophages, and stimulates the proliferation of activated $\mathrm{T}$ and NK cells $[12,20,21]$. Recently, IL-12 has also been reported to act directly on activated B lymphocytes to enhance immunoglobulin secretion [22].

Early production of IL-12 within the first hours of infection has been reported, particularly in the case of intracellular bacteria and parasites [23]. In murine models, endogenously produced IL-12 has been observed to contribute to the control of the host response against infections with intracellular organisms such as Mycobacterium tuberculosis [24], M. avium [25], Legionella pneumophila [26], Borrelia burgdorferi [27], group B streptococci [28], Salmonella dublin [29], Listeria monocytogenes [30], Leishmania major [31], B. abortus [9-11] and Toxoplasma gondii [32]. A possible common mechanism could be associated with the production of IFN- $\gamma$ [10] and the subsequent activation of phagocytic cells, increasing their capacity to destroy the intracellular pathogen [23]. However, neither the dynamics of endogenous IL-12 production during the course of $B$. abortus infection nor its relationship with the evolution of the infectious process have been thoroughly investigated.

An earlier study established that inoculation of CD-1 mice with the virulent 2308 strain of $B$. abortus leads to chronic infection, with the micro-organism being detected up to 12 weeks after infection, and accompanied by production of IFN- $\gamma$ and IL-10 [33]. In the present study, the production of endogenous IL-12 in response to infection with virulent $B$. abortus was investigated in the murine model described previously. The capacity of $B$. abortus 2308 to stimulate secretion of IL-12 and IFN- $\gamma$ by cultured CD-1 peritoneal macrophages was also explored.

\section{Materials and methods}

Mice

Female outbred CD-1 mice (Charles River, Barcelona, Spain) were purchased at 9 weeks of age and kept for 1 week before use. The animals were housed in microisolator cages in Horsefall units and were cared for in accordance with standard guidelines.

\section{Bacterial strain and culture medium}

$B$. abortus 2308 was used as the challenge strain. Virulent B. abortus 2308 was passaged in CD-1 mice and isolated in pure culture from spleens. Stock cultures were prepared from cultures grown for $72 \mathrm{~h}$ at $37^{\circ} \mathrm{C}$ in Tryptic Soy Broth (TSB; BBL Microbiology Systems) enriched with yeast extract (Difco) $0.3 \% \mathrm{w} / \mathrm{v}$ and stored at $-70^{\circ} \mathrm{C}$ in glycerol $50 \% \mathrm{v} / \mathrm{v}$. For challenge, the contents of freshly thawed vials were cultured on Tryptic Soy Agar (TSA; BBL) for $72 \mathrm{~h}$ at $37^{\circ} \mathrm{C}$ in an atmosphere of $\mathrm{CO}_{2} 5 \% \mathrm{v} / \mathrm{v}$ in air. The bacteria were suspended in sterile phosphate-buffered saline (PBS; $\mathrm{pH} 7.4$ ) and adjusted turbidimetrically to the desired concentration. The exact dose was established retrospectively by viable counting.

\section{Experimental infection of mice}

Mice were inoculated intravenously (i.v.) with $0.7 \times$ $10^{6} \mathrm{cfu}$ of $B$. abortus 2308 in $0.1 \mathrm{ml}$ of PBS. To evaluate cytokine production, mice in groups of three were killed by cervical dislocation daily during the first week after inoculation and then weekly from the first to the seventh week after inoculation. Control groups received $0.1 \mathrm{ml}$ of PBS i.v. Before the mice were killed, blood samples were obtained from the tail vein and were stored at $-70^{\circ} \mathrm{C}$ until used.

\section{Preparation of spleen homogenates for bacterial counts and cytokine analysis}

A minor modification of a previously described process was used [33,34]. Briefly, spleens obtained from infected and control mice were homogenised individually at a concentration of $100 \mathrm{mg}$ of spleen $/ \mathrm{ml}$ of Hanks's balanced salts solution (Gibco) containing 3[(3-cholamidopropyl)-dimethylammonio]-1-propanesulphonate (Sigma) $1 \% \mathrm{w} / \mathrm{v}$. A sample of the resulting cell suspension was diluted appropriately in PBS and plated out in triplicate on TSA. After incubation for $72 \mathrm{~h}$ in $\mathrm{CO}_{2} 5 \% \mathrm{v} / \mathrm{v}$, bacterial colonies were counted and expressed as the $\log _{10} /$ organ value. Previous studies had shown that the procedure used to prepare the samples does not affect the viability of the organisms present $[33,34]$. After extraction of cytokines for $1 \mathrm{~h}$ at $4^{\circ} \mathrm{C}$, samples were centrifuged $(10000 \mathrm{~g}$ for $30 \mathrm{~min}$ ) and the supernates were held at $-70^{\circ} \mathrm{C}$ until assayed.

\section{Isolation and infection of $C D-1$ mouse peritoneal macrophages}

Macrophages were isolated as described previously [20], with some modifications. Briefly, 8-10-week-old female CD-1 mice (Charles River) were inoculated intraperitoneally with $0.3 \mathrm{ml}$ of incomplete Freund's adjuvant [35]. Three days later, mice were killed by cervical dislocation and peritoneal cells were harvested by lavage with cold RPMI-1640 containing $2 \mathrm{mM} \mathrm{L-}$ glutamine and supplemented with heat-inactivated fetal calf serum (Gibco) $10 \% \mathrm{v} / \mathrm{v}$ without antibiotics (complete medium). The endotoxin levels of all medium components were $<25 \mathrm{pg} / \mathrm{ml}$ (final concentration). The cell suspensions $(3-4 \mathrm{ml})$ were placed in 25- $\mathrm{cm}^{2}$ tissue-culture flasks (Costar, Cambridge, MA, USA) and macrophages were allowed to adhere for $24 \mathrm{~h}$ in a humidified $\mathrm{CO}_{2} 5 \% \mathrm{v} / \mathrm{v}$ incubator at $37^{\circ} \mathrm{C}$. Non-adhering cells were then washed off and adhering cells were washed three times with $3 \mathrm{ml}$ of complete medium. The adhering cells were then incubated in 
$3 \mathrm{ml}$ of complete medium for $2 \mathrm{~h}$. The number and viability of macrophages obtained by this procedure were determined by morphological examination and Trypan blue exclusion [35]. Bacteria from overnight cultures were opsonised at $37^{\circ} \mathrm{C}$ for $60 \mathrm{~min}$ in PBS containing a subagglutinating dilution ( 1 in 200) of the mouse monoclonal antibody $\mathrm{BmE} 10-5$ with specificity against the lipopolysaccharide (S-LPS) of Brucella spp. [36]. Opsonised bacteria were then centrifuged, washed and diluted in complete medium. Opsonisation had no effect on bacterial survival in vitro. To infect macrophages, different numbers of opsonised $B$. abortus 2308 in complete medium were added for $1 \mathrm{~h}$. After incubation for $1 \mathrm{~h}$, non-phagocytosed bacteria were washed off. Following this, $3 \mathrm{ml}$ of complete medium containing gentamicin (Sigma) $100 \mu \mathrm{g} / \mathrm{ml}$ were added to the macrophages to kill any remaining extracellular bacteria [37]. Then, the cells were cultured at $37^{\circ} \mathrm{C}$ in a $\mathrm{CO}_{2} 5 \% \mathrm{v} / \mathrm{v}$ incubator and, at the indicated time points, culture supernates were obtained from each flask and held at $-70^{\circ} \mathrm{C}$ until used for cytokine analysis. Supernates obtained at the same times from uninfected macrophage cultures were used as negative controls.

In some experiments, macrophage cultures were incubated in complete medium plus gentamicin with purified S-LPS obtained from $B$. abortus 2308 $(20 \mu \mathrm{g} / \mathrm{ml})$ in the presence or absence of IFN- $\gamma$ $(1500 \mathrm{U} / \mathrm{ml}$; Boehringer Mannheim). This B. abortus antigen contained, as percentage of dry weight protein 1.5\% and 2-keto-3-deoxyoctulosonic acid (KDO) 1.1\% [36]. S-LPS from Escherichia coli O26:B6 (Sigma) $5 \mu \mathrm{g} / \mathrm{ml}$ in the presence or absence of IFN- $\gamma$ $(1500 \mathrm{U} / \mathrm{ml})$ was also used to stimulate macrophage cultures. At the indicated time points, culture supernates were obtained from each flask and held at $-70^{\circ} \mathrm{C}$ until assayed. Supernates obtained at the same times from non-treated macrophage cultures were used as negative controls.

\section{Cytokine analysis}

IFN- $\gamma$ and IL-12 levels in serum, whole spleen homogenates and macrophage culture supernates were measured by commercial sandwich enzyme-linked immunosorbent assay (ELISA) kits (Intertest- $\gamma$, Intertest-IL-12X total mouse IL-12 and Intertest-IL-12X mouse IL-12p70, respectively; Genzyme, Cambridge MA, USA). Total mouse IL-12 ELISA detects all three forms of IL-12, i.e., p40 monomer, $(\mathrm{p} 40)_{2}$ homodimer and p70 heterodimer. Protocols were as recommended by the manufacturer. Known concentrations of each cytokine were used to generate standard curves in each assay and used as references to calculate the cytokine concentration present in the samples. Whole spleen homogenates obtained from PBS-treated mice or supernates obtained from uninfected macrophage cultures were used as negative controls in each assay. Results were expressed as the level of each cytokine per ml of sample (spleen extract, serum or macrophage culture supernate) or per $0.1 \mathrm{~g}$ of organ.

\section{Cytotoxicity assay}

This was performed with CellTiter $96^{\mathrm{TM}} \mathrm{AQ}_{\text {ueous }}$ NonRadioactive Cell Proliferation Assay (Promega) kits. Briefly, macrophages were cultured for $24 \mathrm{~h}$ in 96 -well flat-bottomed cell culture plates at $2 \times 10^{5}$ cells/well $(100 \mu 1)$ in complete medium without antibiotics. Nonadhering cells were washed off and the macrophage culture was maintained at $37^{\circ} \mathrm{C}$ for $2 \mathrm{~h}$ in a humidified $\mathrm{CO}_{2} 5 \% \mathrm{v} / \mathrm{v}$ incubator. Bacteria, opsonised as described above, were added to each well and, after incubation for $1 \mathrm{~h}$, non-phagocytosed bacteria were washed off and macrophages were cultured for 24 or $48 \mathrm{~h}$ in complete medium with gentamicin $100 \mu \mathrm{g} / \mathrm{ml}$. Macrophage viability was determined by measuring the $\mathrm{A}_{490}$ values of eight wells containing cells of the same multiplicity of infection. Results are presented as the means of eight determinations and standard deviations were $<10 \%$ of the mean values.

\section{Statistical methods}

Statistical analyses were performed with Student's $t$ test and the StatView computer program. A p value $<0.05$ was considered statistically significant.

\section{Results \\ IL-12 production during the course of B. abortus infection of mice}

As shown in Fig. 1a, total IL-12 was significantly enhanced in sera and in whole spleen homogenates between the first and seventh day after inoculation, reaching maximum levels on the fifth $(5.9 \mathrm{ng} / \mathrm{ml})$ and fourth $(3.4 \mathrm{ng} / \mathrm{ml})$ day, respectively. Endogenous production of this cytokine during the first week after inoculation was correlated with a significant increase $(\mathrm{p}<0.001)$ in the number of viable $B$. abortus 2308 in the spleens of inoculated mice (Fig. 1a). An increase in the number of bacteria in the spleens was also observed during the second week (Fig. 1b), together with an increase in the production of total IL-12 in serum and spleen homogenates. Between the second and seventh weeks after inoculation the numbers of $B$. abortus in the spleens decreased significantly $(p<0.001)$, along with a significant diminution in the levels of total IL-12 in serum and spleen homogenates (Fig. 1b). The levels of total IL-12 in sera and whole spleen homogenates obtained at the same times from control PBS-treated mice were always $<15 \mathrm{pg} / \mathrm{ml}$.

When the levels of the bioactive $p 70$ heterodimer were measured by a sensitive and specific ELISA (Fig. 2), this immunoactive form of IL-12 was detected only during the first 4 days after inoculation and in much lower amounts than the monomeric p40 and dimeric 


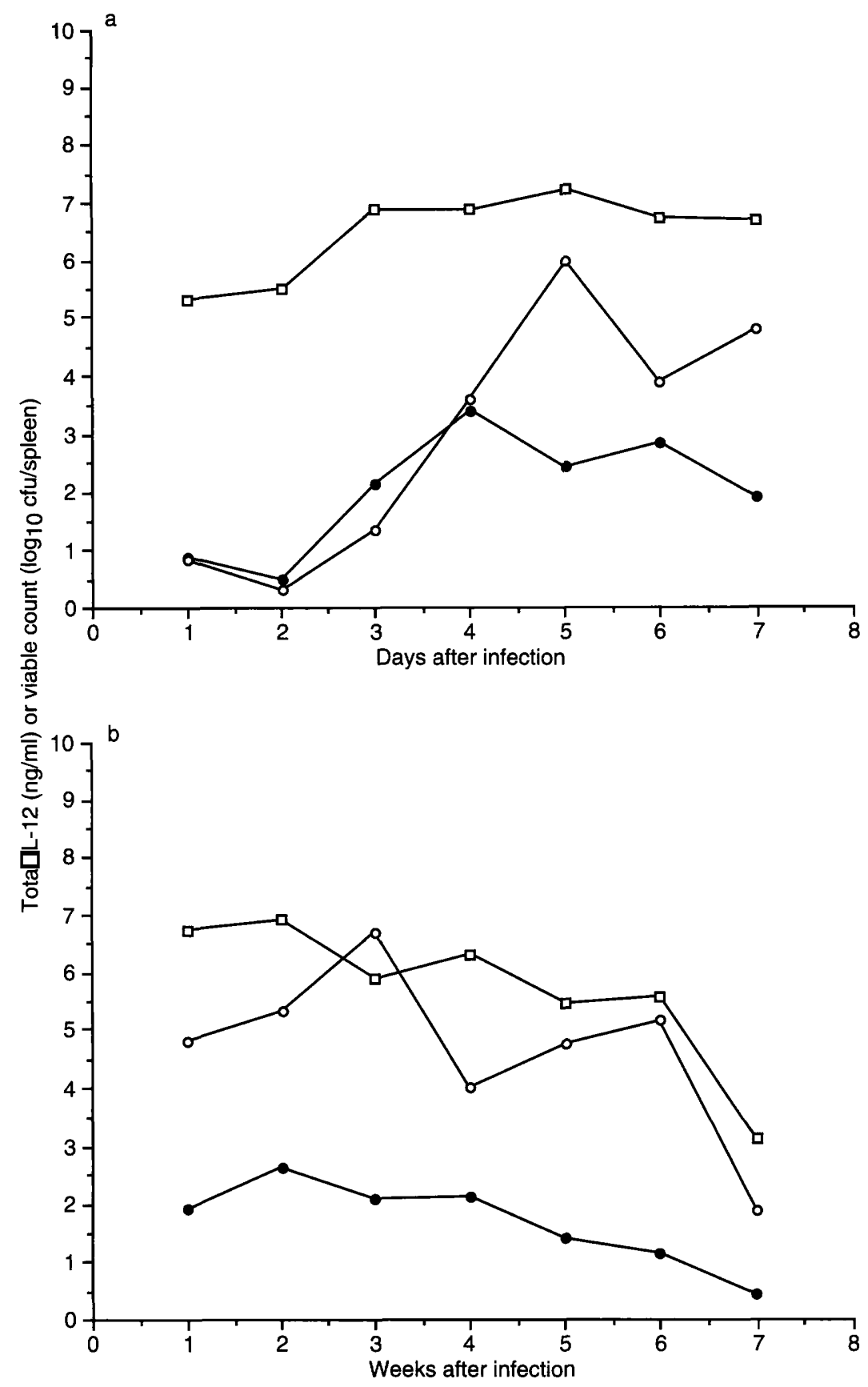

Fig. 1. Levels of total IL-12 in serum (O) and whole spleen homogenates ( $\bullet$ ) and growth curve ( $\square$ ) of $B$. abortus in spleens of CD-1 mice after i.v. injection of $0.7 \times 10^{6} \mathrm{cfu}$ of $B$. abortus strain 2308. (a) First 7 days after infection (b) First 7 weeks after infection. Each symbol represents the mean of three mice. SDs were $<15 \%$ of mean values. The levels of total IL-12 in samples from PBS-treated mice (control group) were always $<15 \mathrm{pg} / \mathrm{ml}$. The lowest detection limit of total IL-12 was $10 \mathrm{pg} / \mathrm{ml}$.

(p40) $)_{2}$ forms of this interleukin. Maximum levels of IL-12p70 in serum and spleen homogenates were 216.6 and $198.9 \mathrm{pg} / \mathrm{ml}$, respectively, on the first and the third day. The levels of IL-12p70 in sera and whole spleen homogenates obtained at the same times from control PBS-treated mice were always $<8 \mathrm{pg} / \mathrm{ml}$.

\section{B. abortus-induced secretion of IL-12p40 and IL-} $12(p 40)_{2}$ by $C D-1$ macrophages

During the course of infection, professional phagocytes are the first target for invasion by Brucella spp. and the pathogen may survive within these cells $[1,2]$. Moreover, together with $\mathrm{B}$ cells, phagocytic cells are the main producers of IL-12 [12,13]. To determine the effect that intracellular infection by the bacterium might have on the production of this cytokine, it was first necessary to determine the number of $B$. abortus cells that could be added to macrophage cultures without significantly altering their viability. Table 1 shows that at $24 \mathrm{~h}$ after exposure, once extracellular bacteria had been eliminated by the addition of gentamicin to the macrophage culture, intracellular bacteria induced a dose-dependent decrease in the 


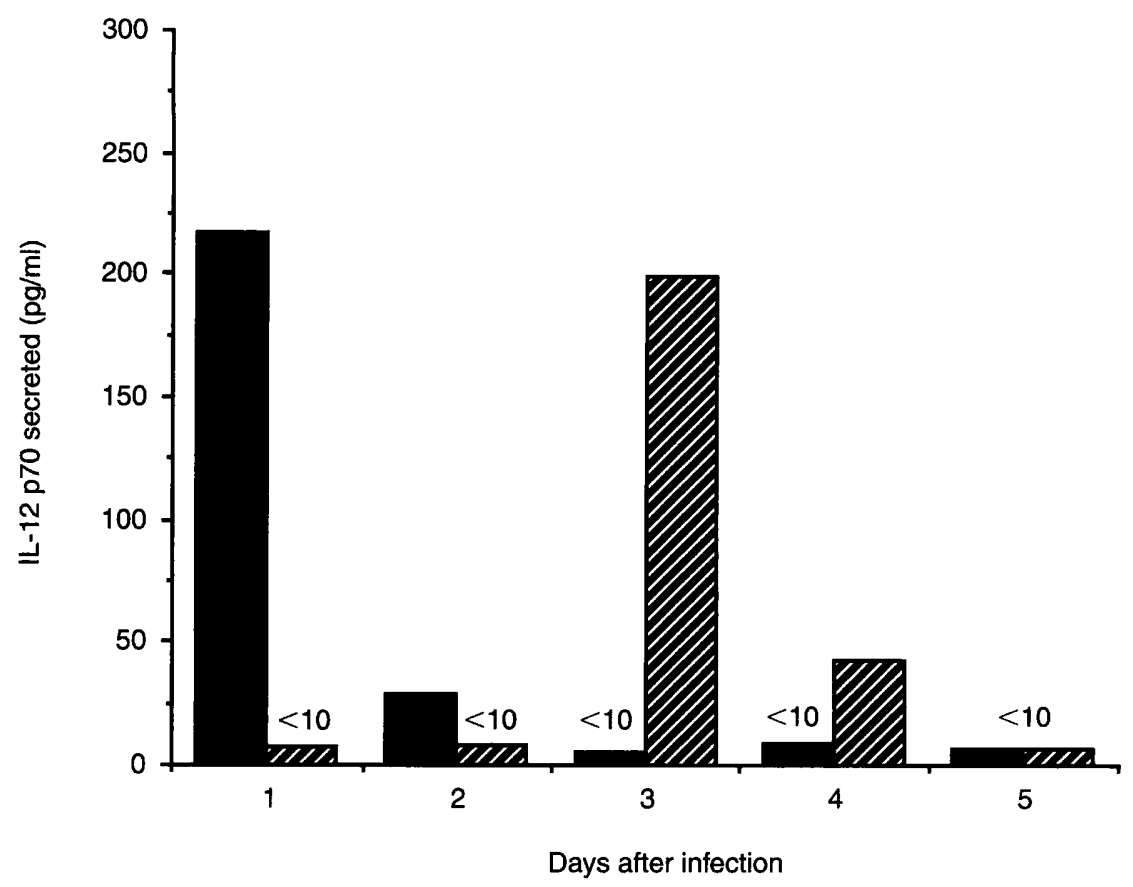

Fig. 2. Levels of IL-12 p70 in serum (ם) and whole spleen homogenates (ש: of CD-1 mice after i.v. injection of $0.7 \times 10^{6} \mathrm{cfu}$ of $B$. abortus 2308. Results are the means of three mice and SDs were $<15 \%$ of mean values. The levels of IL-12p70 in samples from PBS-treated mice (control group) were always $<8 \mathrm{pg} / \mathrm{ml}$. The lowest detection limit of IL- $12 \mathrm{p} 70$ was $5 \mathrm{pg} / \mathrm{ml}$.

Table 1. Determination of macrophage viability after infection with B. abortus 2308

\begin{tabular}{lcc}
\hline & \multicolumn{2}{c}{ Macrophage viability $(\%)^{*}$ at } \\
\cline { 2 - 3 } Challenge dose $^{\dagger}$ & $24 \mathrm{~h}$ & $48 \mathrm{~h}$ \\
\hline $100: 1$ & 37 & 17 \\
$30: 1$ & 56 & 51 \\
$10: 1$ & 69 & 61 \\
$3: 1$ & $>98$ & 89 \\
$1: 1$ & $>98$ & $>98$ \\
$0.3: 1$ & $>98$ & $>98$ \\
\hline
\end{tabular}

${ }^{*}$ Macrophage viability was determined by the CellTiter $96^{\mathrm{TM}} \mathrm{AQ}_{\text {ueous }}$ Non-Radioactive Cell Proliferation Assay (see text). Results are presented as means of eight determinations. SD values were $<10 \%$ of mean values.

${ }^{\dagger} B$. abortus: macrophage ratio.

number of viable macrophages. This effect was greater at $48 \mathrm{~h}$ after exposure.

The ability of $B$. abortus 2308 to induce secretion of bioactive p70 heterodimer and inactive p 40 monomeric and $(\mathrm{p} 40)_{2}$ dimers in cultured CD-1 macrophages was assessed by a sensitive ELISA assay. CD-1 macrophages $\left(10^{7}\right.$ cells) were infected with different numbers of opsonised B. abortus 2308 cells ranging from $0.3 \times 10^{7}$ to $3 \times 10^{8} \mathrm{cfu}$. After incubation for $1 \mathrm{~h}$, extracellular bacteria were eliminated by successive washings and the addition of gentamicin, and infected cultures were incubated for $48 \mathrm{~h}$. Fig. 3 shows that, at $48 \mathrm{~h}$ after exposure, macrophages secreted substantial amounts of total IL-12 in response to intracellular bacteria. The secretion of the cytokine was dosedependent, with a maximum secretion of $1010.1 \mathrm{pg} / \mathrm{ml}$ at a challenge dose of 30:1 (bacteria:macrophage). However, macrophages did not secrete detectable amounts of IL-12p70, the immunoactive form of IL12 (detection limit of the ELISA assay $5 \mathrm{pg} / \mathrm{ml}$ ). Different assays were performed with up to $10^{9} \mathrm{cfu}$ of B. abortus $/ 10^{7}$ macrophages, but no secretion of IL12 p70 was detected. The challenge dose of $30: 1$ was selected to assess the secretion kinetics of total IL-12 at 24,48 and $72 \mathrm{~h}$ after exposure (Fig. 4). Maximum secretion $(878.4 \mathrm{pg} / \mathrm{ml})$ was observed at $24 \mathrm{~h}$ after exposure. Again, no IL-12p70 secretion was detected.

The inability of $B$. abortus 2308 to induce IL-12p70 secretion in cultured macrophages cannot be explained by the incapacity of the macrophages to secrete this form of IL-12. Macrophages cultured with S-LPS $(20 \mu \mathrm{g} / \mathrm{ml})$ from B. abortus 2308 or S-LPS $(5 \mu \mathrm{g} / \mathrm{ml})$ from $E$. coli $\mathrm{O} 26: \mathrm{B} 6$ secreted detectable amounts of IL-12p70 (16.2 pg/ml and $24.7 \mathrm{pg} / \mathrm{ml}$, respectively; data not shown). These S-LPS preparations were also potent inducers of IL-12 p40 and (p40) $)_{2}$ secretion (Figs. 3 and 4).

\section{B. abortus induced secretion of IFN- $\gamma$ by $C D-1$ macrophages}

A possible mechanism through which IL-12 contributes to resistance to $B$. abortus infection would be via an IFN- $\gamma$-dependent pathway $[9,10]$. As shown in Fig. 5, $B$. abortus 2308 induced the secretion of IFN- $\gamma$ by CD-1 peritoneal macrophages. Maximum secretion $(520.1 \mathrm{pg} / \mathrm{ml})$ was demonstrated at $24 \mathrm{~h}$ after infection. Similarly, in response to stimulation by S-LPS $(20 \mu \mathrm{g} / \mathrm{ml})$ from $B$. abortus 2308 , CD-1 peritoneal macrophages also released substantial amounts of IFN$\gamma(105.1 \mathrm{pg} / \mathrm{ml}$ at $48 \mathrm{~h})$ (Fig. 5). 


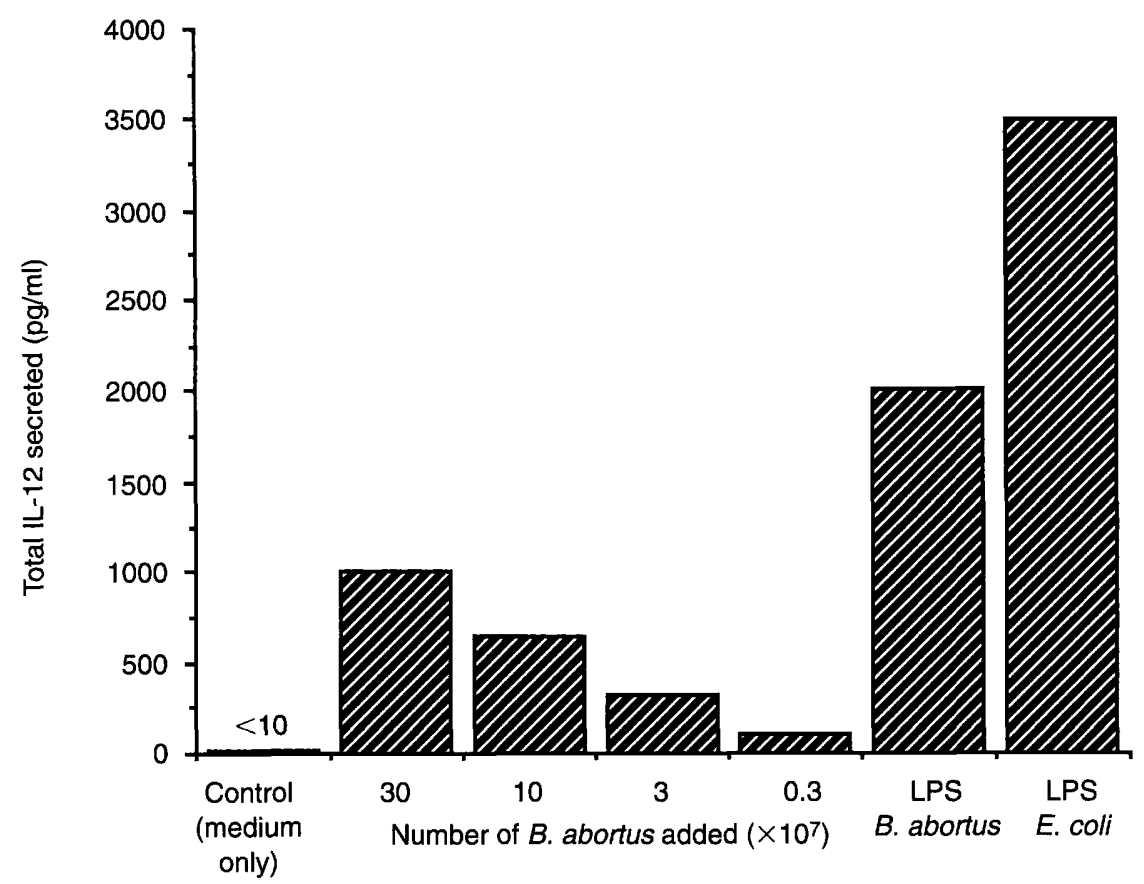

Fig. 3. Secretion of total IL-12 by cultured CD-1 peritoneal macrophages $\left(10^{7}\right.$ cells) in response to different numbers of opsonised B. abortus 2308 cells and to S-LPS preparations. Results obtained at $48 \mathrm{~h}$ after infection are mean values of triplicate ELISA determinations and SDs were $<15 \%$ of mean values. Negative controls of total IL-12 production included supernates obtained at $48 \mathrm{~h}$ from macrophages in culture medium only. The lowest detection limit of total IL12 was $10 \mathrm{pg} / \mathrm{ml}$. Similar results were observed in at least two other experiments.

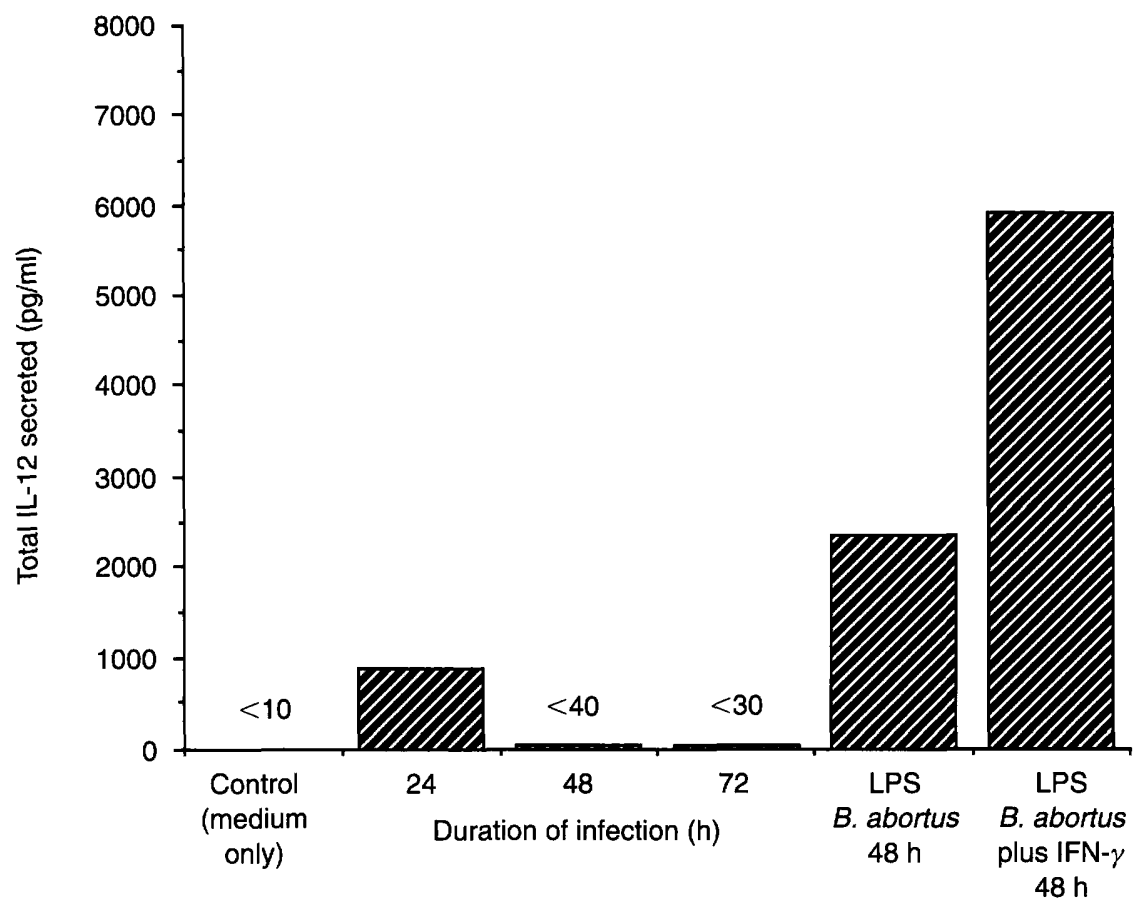

Fig. 4. Kinetics of total IL-12 secretion by cultured CD-1 peritoneal macrophages $\left(10^{7}\right.$ cells) in response to infection with $3 \times 10^{8} \mathrm{cfu}$ of opsonised $B$. abortus 2308 . Results obtained at 24,48 and $72 \mathrm{~h}$ after infection are mean values of triplicate ELISA determinations and SDs were $<15 \%$ of mean values. Negative controls of total IL-12 production included supernates obtained at each time point from macrophages in culture medium only. Positive controls were supernates from macrophages treated with B. abortus S-LPS $(20 \mu \mathrm{g} / \mathrm{ml})$ with or without IFN- $\gamma(1500 \mathrm{U} / \mathrm{ml})$. The lowest detection limit of total IL-12 was $10 \mathrm{pg} / \mathrm{ml}$. Similar results were obtained in at least two other experiments.

\section{Discussion}

Previous reports have indicated that endogenous IL-12 is produced in the course of $B$. abortus infection in a murine model, contributing to resistance to infection $[9,10]$. In the present study, these aspects have been broadened and CD-1 mouse and CD-1 cultured peritoneal macrophages were used to analyse the 


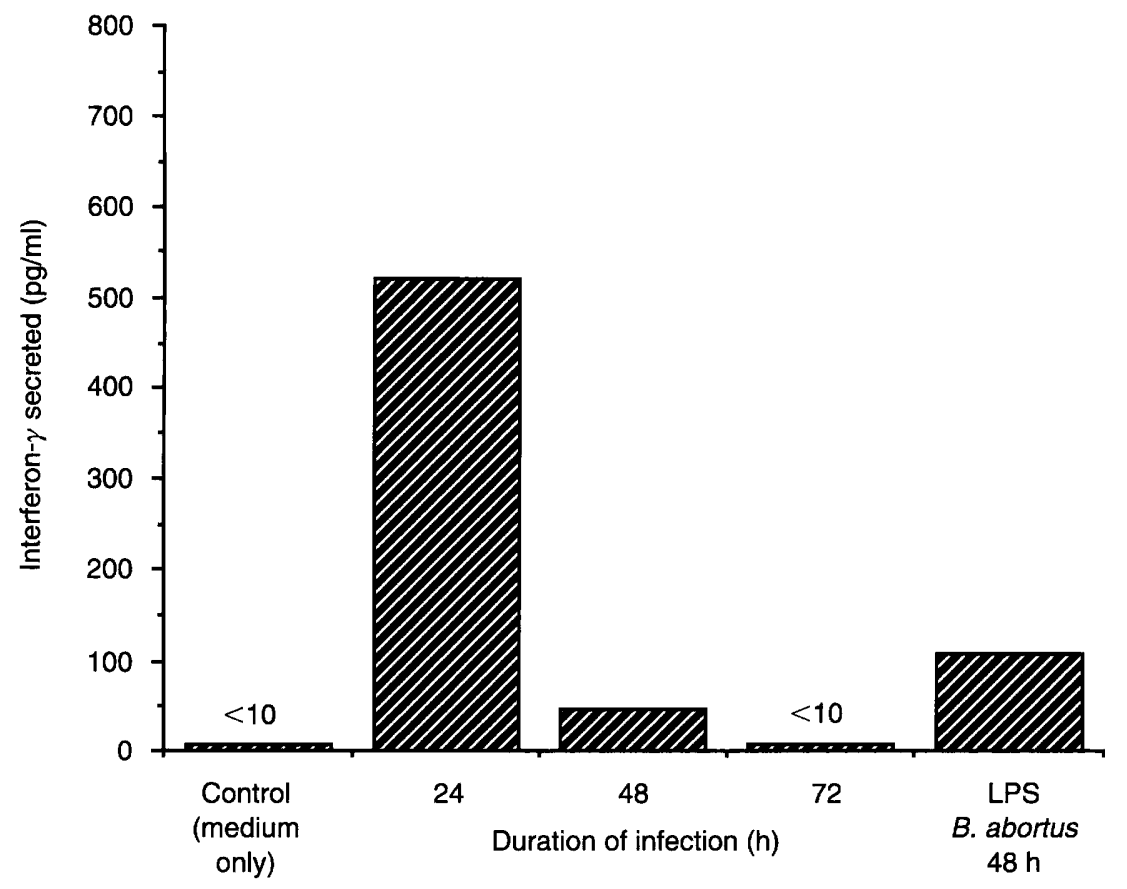

Fig. 5. Kinetics of IFN- $\gamma$ secretion by cultured CD-1 peritoneal macrophages $\left(10^{7}\right.$ cells $)$ in response to infection with $3 \times 10^{8} \mathrm{cfu}$ of opsonised B. abortus 2308 . Results obtained at 24,48 and $72 \mathrm{~h}$ after infection are mean values of triplicate ELISA determinations and SDs were $<15 \%$ of mean values. Negative controls of IFN- $\gamma$ production included supernates obtained at each time point from macrophages in culture medium only. Positive controls were supernates from macrophages treated with $B$. abortus S-LPS $(20 \mu \mathrm{g} / \mathrm{ml})$. The lowest detection limit of IFN- $\gamma$ was $5 \mathrm{pg} / \mathrm{ml}$. Similar results were observed in at least two other experiments.

kinetics of production of the different biological forms of this cytokine (immunoactive IL-12p70 and free inactive p40 subunits), to determine their relationship to the development of an infection with virulent $B$. abortus 2308 and its tendency to become chronic.

In the assays performed in vivo and in vitro, quantitative differences in the secretion of the free inactive p40 subunits of IL-12 and the bioactive form p70 of this cytokine were observed. Thus, by ELISA on the culture supernates from CD-1 peritoneal macrophages infected with $B$. abortus 2308 , significant levels of only the non-immunoactive monomeric (p40) and dimeric $(\mathrm{p} 40)_{2}$ forms of IL-12 were detected. In contrast, with the same ELISA on serum and whole spleen homogenates from mice infected i.v. with $B$. abortus 2308, much higher levels of these biologically inactive forms of IL-12 were detected, as well as the production of the p70 immunoactive form, mainly during the first days after infection. A similar picture has been observed in vivo and in vitro in the secretion of IL-12 induced by $S$. dublin, another facultative intracellular micro-organism $[29,35]$. In view of these results, at present it is not possible to rule out the notion that different factors, hitherto unidentified and generated in vivo during the course of infection by $B$. abortus, would be required to induce the synthesis of the immunoactive form of this interleukin more efficiently. However, the biological relevance of these results is considerable, as it has been established experimentally that the secreted IL-12p40 subunit and IL-12p40 homodimers may function as antagonists of
IL-12p70 bioactivity $[14,16,17]$. Thus $B$. abortus may interfere with the establishment of immunity induced by IL- 12 by stimulating mainly the secretion of the non-immunoactive forms of this interleukin and downregulating the secretion of the bioactive form IL-12p 70 .

In murine models of infection with $B$. abortus [9] and with other intracellular pathogens $[24-27,29,30]$, the neutralisation of endogenously synthesised IL-12 is associated with an exacerbation of the infection. In the present study, the low levels of the bioactive form of IL12 p70 demonstrated in serum and whole spleen homogenates of mice infected with $B$. abortus could be sufficient to control the multiplication of the microorganism (Figs. 1a and 1b), possibly via an IFN- $\gamma$ dependent route $[8,10]$. It should also be noted that the heterodimeric IL-12p70 may not necessarily be secreted in a soluble form and may function as a membranebound protein on macrophages [38]. Under these circumstances, the levels of soluble IL-12p70 would be low, accounting for the results obtained here with the specific ELISA. In any case, and regardless of the mechanism of secretion of the heterodimer $\mathrm{p} 70$, the bacteria presisted in the spleens of the mice for at least seven weeks. Others have reported persistence of the organism at 14 [33] and 20 [39] weeks after infection. In consequence, pro-inflammatory and regulatory cytokines synthesised in the course of infection of CD-1 mice by $B$. abortus 2308 are not sufficient per se to induce an effective protective response and to prevent the infection from becoming chronic. Possibly, as with other micro-organisms [24, 28, 29, 40-43], the admin- 
istration of exogenous IL-12 before or during infection by $B$. abortus might favour the induction of different effector mechanisms and afford better protection against the infectious agent. Therefore, further research should be conducted to establish the possible beneficial effects of cytokine therapy on the course of $B$. abortus infections.

The results obtained in the present study also demonstrate that, in addition to IL-12, cultures of CD-1 peritoneal macrophages also secrete substantial amounts of IFN- $\gamma$ in response to $B$. abortus 2308 infection. Similar findings have been reported recently [44] for cultured human alveolar macrophages stimulated with $M$. tuberculosis. As it has been established that this secreted IL-12 is responsible for the induction of IFN- $\gamma$ production by human alveolar and murine peritoneal macrophages $[44,45]$, it is possible that the IL-12 secreted by CD-1 peritoneal macrophages in response to $B$. abortus 2308 might play a role in the secretion of IFN- $\gamma$ by these cells. Further research will also be required to elucidate the role of the secreted IFN- $\gamma$ in the activation and in the microbicidal activities of $B$. abortus-infected peritoneal macrophages.

This work was supported by a grant from the 'Junta de Castilla y León', Spain.

\section{References}

1. Baldwin CL, Winter AJ. Macrophages and Brucella. Immunol Ser 1994; 60: 363-380.

2. Liautard JP, Gross A, Doonand J, Kohler S. Interactions between professional phagocytes and Brucella spp. Microbiología 1996; 12: $197-206$.

3. Pizarro-Cerdá J, Moreno E, Sanguedolce V, Mege J-L, Gorvel J-P. Virulent Brucella abortus prevents lysosome fusion and is distributed within autophagosome-like compartments. Infect Immun 1998; 66: 2387-2392.

4. Araya LN, Elzer PH, Rowe GE, Enright FM, Winter AJ. Temporal development of protective cell-mediated and humoral immunity in BALB/c mice infected with Brucella abortus. $J$ Immunol. 1989; 143: 3330-3337.

5. Zhan Y, Yang J, Cheers C. Cytokine response of T-cell subsets from Brucella abortus-infected mice to soluble Brucella proteins. Infect Immun 1993; 61: 2841-2847.

6. Fernandes DM, Baldwin CL. Interleukin-10 downregulates protective immunity to Brucella abortus. Infect Immun 1995; 63: $1130-1133$.

7. Jiang $\mathrm{X}$, Baldwin CL. Effect of cytokines on intracellular growth of Brucella abortus. Infect Immun 1993; 61: 124-134.

8. Zhan Y, Cheers C. Endogenous gamma interferon mediates resistance to Brucella abortus infection. Infect Immun 1993; 61: 4899-4901.

9. Zhan Y, Cheers C. Endogenous interleukin-12 involved in resistance to Brucella abortus infection. Infect Immun 1995; 63: 1387-1390.

10. Zhan Y, Liu Z, Cheers C. Tumor necrosis factor alpha and interleukin-12 contribute to resistance to the intracellular bacterium Brucella abortus by different mechanisms. Infect Immun 1996; 64: 2782-2786.

11. Zhan Y, Cheers C. Control of IL-12 and IFN- $\gamma$ production in response to live or dead bacteria by TNF and other factors. $J$ Immunol 1998; 161: 1447-1453.

12. Stern AS, Podlaski FJ, Hulmes JD et al. Purification to homogeneity and partial characterization of cytotoxic lymphocyte maturation factor from human B-lymphoblastoid cells. Proc Natl Acad Sci USA 1990; 87: 6808-6812.
13. Cassatella MA, Meda L, Gasperini S, D'Andrea A, Ma X, Trinchieri G. Interleukin-12 production by human polymorphonuclear leukocytes. Eur J Immunol 1995; 25: 1-5.

14. Gillessen S, Carvajal D, Ling P et al. Mouse interleukin-12 (IL12) p40 homodimer: a potent IL-12 antagonist. Eur J Immunol 1995; 25: 200-206.

15. Skeen MJ, Miller MA, Shinnick TM, Ziegler HK. Regulation of murine macrophage IL-12 production. Activation of macrophages in vivo, restimulation in vitro, and modulation by other cytokines. J Immunol 1996; 156: 1196-1206.

16. Gately MK, Carvajal DM, Connaughton SE et al. Interleukin-12 antagonist activity of mouse interleukin-12 p40 homodimer in vitro and in vivo. Ann N Y Acad Sci 1996; 795: 1-12.

17. Heinzel FP, Hujer AM, Ahmed FN, Rerko RM. In vivo production and function of IL-12 p40 homodimers. J Immunol 1997; 158: 4381-4388.

18. Manetti R, Parronchi P, Guidizi MG et al. Natural killer cell stimulatory factor (interleukin 12 [IL-12]) induces $\mathrm{T}$ helper type 1 (Th1)-specific immune responses and inhibits the development of IL-4 producing Th cells. J Exp Med 1993; 177: 1199-1204.

19. Trinchieri G. Interleukin-12 and its role in the generation of Th1 cells. Immunol Today 1993; 14: 335-337.

20. Biron CA, Gazzinelli RT. Effects of IL-12 on immune responses to microbial infections: a key mediator in regulating disease outcome. Curr Opin Immunol 1995; 7: 485-496.

21. Trinchieri G. Interleukin-12: a cytokine produced by antigenpresenting cells with immunoregulatory functions in the generation of T-helper cells type 1 and cytotoxic lymphocytes. Blood 1994; 84: 4008-4027.

22. Jelinek DF, Braaten JK. Role of IL-12 in human B lymphocyte proliferation and differentiation. J Immunol 1995; 154: 1606-1613.

23. Trinchieri G. Proinflammatory and immunoregulatory functions of interleukin-12. Int Rev Immunol 1998; 16: 365-396.

24. Cooper AM, Roberts AD, Rhoades ER, Callahan JE, Getzy DM, Orme IM. The role of interleukin-12 in acquired immunity to Mycobacterium tuberculosis infection. Immunology 1995; 84: 423-432.

25. Saunders BM, Zhan Y, Cheers C. Endogenous interleukin-12 is involved in resistance of mice to Mycobacterium avium complex infection. Infect Immun 1995; 63: 4011-4015.

26. Brieland JK, Remick DG, LeGendre ML, Engleberg NC, Fantone JC. In vivo regulation of replicative Legionella pneumophila lung infection by endogenous interleukin-12. Infect Immun 1998; 66: 65-69.

27. Anguita J, Samanta S, Barthold SW, Fikrig E. Ablation of interleukin-12 exacerbates Lyme arthritis in SCID mice. Infect Immun 1997; 65: 4334-4336.

28. Mancuso G, Cusumano V, Genovese F, Gambuzza M, Beninati C, Teti G. Role of interleukin 12 in experimental neonatal sepsis caused by group B streptococci. Infect Immun 1997; 65: 3731-3735.

29. Kincy-Cain T, Clements JD, Bost KL. Endogenous and exogenous interleukin-12 augment the protective immune response in mice orally challenged with Salmonella dublin. Infect Immun 1996; 64: 1437-1440.

30. Emoto Y, Emoto M, Kaufmann SHE. Transient control of interleukin-4-producing natural killer $\mathrm{T}$ cells in the livers of Listeria monocytogenes-infected mice by interleukin-12. Infect Immun 1997; 65: 5003-5009.

31. Mattner F, Di Padova K, Alber G. Interleukin-12 is indispensable for protective immunity against Leishmania major. Infect Immun 1997; 65: 4378-4383.

32. Walker W, Roberts CW, Ferguson DJP, Jebbari H, Alexander J. Innate immunity to Toxoplasma gondii is influenced by gender and is associated with differences in interleukin-12 and gammainterferon production. Infect Immun 1997; 65: 1119-1121.

33. Fernández-Lago L, Monte $M$, Chordi A. Endogenous gamma interferon and interleukin-10 in Brucella abortus 2308 infection in mice. FEMS Immunol Med Microbiol 1996; 15: 109-114.

34. Nakajima R, Brubaker RR. Association between virulence of Yersinia pestis and suppression of gamma interferon and tumor necrosis factor alpha. Infect Immun 1993; 61: 23-31.

35. Bost KL, Clements JD. Intracellular Salmonella dublin induces substantial secretion of the 40-kilodalton subunit of interleukin-12 (IL-12) but minimal secretion of IL-12 as a 70-kilodalton protein in murine macrophages. Infect Immun 1997; 65: 3186-3192.

36. Vizcaino N, Chordi A, Fernández-Lago L. Characterization of smooth Brucella lipopolysaccharides and polysaccharides by monoclonal antibodies. Res Microbiol 1991; 142: 971-978. 
37. Elsinghorst EA. Measurement of invasion by gentamicin resistance. Methods Enzymol 1994; 236: 405-420.

38. Fan X, Sibalic V, Niederer E, Wüthrich RP. The proinflammatory cytokine interleukin- 12 occurs as a cell membrane-bound form on macrophages. Biochem Biophys Res Commun 1996; 225: $1063-1067$

39. Stevens MG, Olsen SC, Pugh GW, Palmer MV. Immune and pathologic responses in mice infected with Brucella abortus 19, RB51, or 2308. Infect Immun 1994; 62: 3206-3212.

40. Bohn E, Schmitt E, Bielfeldt C, Noll A, Schulte R, Autenrieth IB. Ambiguous role of interleukin-12 in Yersinia enterocolitica infection in susceptible and resistant mouse strains. Infect Immun 1998; 66: 2213-2220.

41. Hunter CA, Slifer T, Araujo F. Interleukin-12-mediated resistance to Trypanosoma cruzi is dependent on tumor necrosis factor alpha and gamma interferon. Infect Immun 1996; 64: 2381-2386.

42. Kobayashi K, Kasama T, Yamazaki J et al. Protection of mice from Mycobacterium avium infection by recombinant interleukin-12. Antimicrob Agents Chemother 1995; 39: 1369-1371.

43. Wang Z-E, Zheng S, Corry DB et al. Interferon $\gamma$-dependent effects of interleukin 12 administered during acute or established infection due to Leishmania major. Proc Natl Acad Sci USA 1994; 91: 12932-12936.

44. Fenton MJ, Vermeulen MW, Kim S, Burdick M, Strieter RM, Kornfeld $\mathrm{H}$. Induction of gamma interferon production in human alveolar macrophages by Mycobacterium tuberculosis. Infect Immun 1997; 65: 5149-5156.

45. Puddu P, Fantuzzi L, Borghi P et al. IL-12 induces IFN-gamma expression and secretion in mouse peritoneal macrophages. J Immunol 1997; 159: 3490-3497. 